\title{
Interfering Busybody or Public-Minded Citizen? The Actio Popularis as a Model for Reform of the Rules of Standing in Constitutional Cases in Australia
}

\author{
Bede Harris $^{1}$ \& Elizabeth Harris ${ }^{2}$ \\ ${ }^{1}$ School of Accounting and Finance, Charles Sturt University, Australia \\ ${ }^{2}$ BA/LLB (Hons) student, Australian National University, Australia \\ Correspondence: Dr Bede Harris, School of Accounting and Finance, Charles Sturt University, Locked Bag 119, \\ Kingston Act 2604, Australia. E-mail: beharris@csu.edu.au
}

\author{
Received: December 4, 2017 Accepted: January 3, 2018 Online Published: February 25, 2018 \\ doi:10.5539/jpl.v11n1p62 \\ URL: https://doi.org/10.5539/jpl.v11n1p62
}

\begin{abstract}
The interpretation given by the courts to the word 'matter' in sections 75 and 76 of the Commonwealth of Australia Constitution, and the restrictive approach taken by the courts to what amounts to a sufficient interest in a matter, have led to the consequence that only litigants who can demonstrate a personal interest can bring an action to challenge a breach of the Constitution. This provides insufficient protection for constitutionalism because it means that the enforcement of the Constitution is contingent on there being a self-interested applicant who will bring an action - and, conversely, creates the risk that breaches of the Constitution will be allowed to stand in cases where those who do have standing find it in their political interests to refrain from taking action. With its focus on personal interest, the current approach excludes the altruistic applicant and runs counter to the theory that all citizens have a right to ensure that the Constitution is complied with. This paper examines the way in which the actio popularis of Roman law served the ideal of the engaged citizen by enabling citizens to initiate legal action to enforce public duties, and how modern equivalents of the actio in a number of jurisdictions achieve the same purpose. The paper draws on John Rawls' theory of justice in arguing for reform of the law on standing in Australia so as to confer open standing in constitutional cases.
\end{abstract}

Keywords: Actio popularis, Australia, Chapter III, Commonwealth, constitution, locus standi, matter, Rawls, Roman law, standing

\section{Introduction}

Writing on the role of orators, ${ }^{1}$ the ancient Roman historian Tacitus questioned whether there can be

... any safer line to take than the practice of an art which gives you an ever-ready weapon with which

to ... succour those to whom you are a stranger, to bring deliverance to those in jeopardy....

It is Tacitus' reference to 'stranger(s)' which has the greatest relevance to the issue addressed in this article. The Roman Republic was protected, in part, by the engaged citizen who devoted his talents to the polity in a variety of ways, including by engaging in litigation even in the absence of any particular personal interest in a matter. This was possible because of the availability in Roman law of a public interest action, the actio popularis, which enabled litigants to bring actions to enforce compliance with public duties. The need for such an action is as vital in modern day Australia as it was in Ancient Rome, yet Australia's strict rules of standing prevent the engaged citizen from providing 'succour' to strangers. The public interest litigant has frequently been characterised by the courts as a 'mere intermeddler or busybody' ${ }^{2}$ rather than being lauded as a public-spirited citizen. The effect of this is particularly harmful in the area of Commonwealth constitutional law, where the lack of open standing means that citizens have no ability to initiate legal action to enforce the Constitution

Part 2 of this article explores the actio popularis of Roman law. Part 3 examines analogues of the actio popularis in modern legal systems. Part 4 examines the current law of standing in Australia. Part 5 critiques the Australian

\footnotetext{
1 Tacitus, Dialogue on Oratory 5. (1914) Peterson, W. (Trans.). London: William Heinemann 26-7.

${ }^{2}$ United States Tobacco Co v Minister for Consumer Affairs (1988) 20 FCR 520 at 527 (Davies, Wilcox and Gummow JJ).
} 
law, arguing that current rules are inconsistent and offer insufficient protection for the constitutional order. Part 6 presents arguments in favour of reform, taking a novel approach based on the theories of John Rawls. The article concludes in Part 7, recommends the adoption of rules providing for open standing in constitutional cases, modelled on the actio popularis, outlining how this could be achieved either through judicial development or by means of statutory enactment.

\section{The Actio Popularis as a Model for Rules of Standing in Constitutional Matters}

\subsection{Classical Concepts of State and Citizenship}

Before discussing the Roman law actio popularis, it is necessary to explore Graeco-Roman concepts of citizenship, because this explains the social and political background of the actio.

One of the most insightful explanations of the role of the engaged citizen emerges from the Apology, in which Plato recorded the defence presented by Socrates at his trial on charges of impiety towards the gods and of corrupting the youth. ${ }^{3}$ In the Apology, Socrates says that his public engagement had taken the form of acting as a 'gadfly' for the city, provoking discussion to encourage the public to concern itself with virtue rather than with superficial concerns in order to improve the moral health of the state. In similar vein, Aristotle defined the good citizen as one who actively engaged in public affairs. ${ }^{4}$

The Greek concept of the engaged citizen was echoed in Rome. The pre-eminent exponent of the role of the engaged citizen in ancient Rome was Cicero who, writing during the period of political turmoil that afflicted the Roman Republic in the century following the overthrow of the Gracchi, argued that virtus (or excellence of character) meant more than a state of mind and had to find expression in action, more particularly in engagement in public affairs. ${ }^{5}$ Thus the pursuit of public office and progression through the magistracies was considered the most noble ambition for the Roman citizen. However, Cicero emphasised that involvement in politics should be motivated by concern for the public good, not merely self-aggrandisement and the accumulation of power. For this reason he was scathing about what he considered the blindness of citizens to threats to their liberty posed by the dictatorship of Julius Caesar and their acceptance of largesse from him. ${ }^{6}$

But involvement in public affairs embraced far more than just running for office. The fact that Rome was a republic is critical to an understanding of the broader role of the citizen. As the res publica - the 'public thing' the republic was the common property of the people, an institution in which all citizens had an interest. ${ }^{7}$ This interest was not only a generalised one as a member of the citizen body, but a personal one as well: Every citizen had a duty to intervene when the res publica was threatened, because the ultimate duty of the citizen was that which he owed to the res publica. ${ }^{8}$ Therefore, just as a person could hold enforceable legal rights such possession and ownership in relation to a res, or thing, under the law of property, so too did he enjoy rights in relation to the res publica - the public thing - which could be vindicated by means of a specific legal action, the actio popularis. ${ }^{9}$ By affording the citizen the legal mechanism for vindication of the rules governing the res publica, the actio popularis gave practical form to the values underlying Roman politics. Initiating legal action to ensure that public duties were complied with was viewed as a natural activity for the citizen, as the Republic had as great a call on the conscience of the citizen as did the dictates of the gods. The adoption of an interventionist stance by the citizen was thus seen as a public benefit- an attitude which contrasts sharply with the characterisation in modern case law of the public interest litigant without a personal stake in a controversy as an officious 'busybody' to whom standing should be denied. ${ }^{10}$

\subsection{The Scope of the Actio Popularis}

The actio popularis was defined in the Digest of Justinian at D 47.23.1 as follows:

Eam popularem actionem dicumus, quae suum ius populi tuetur.

\footnotetext{
${ }^{3}$ Plato, Apology. (1914). Fowler, H.N. (Trans). London: William Heinemann 110-13.

${ }^{4}$ Aristotle, Politics, III: 4. (1932). Rackam, H. (Trans.). London: William Heinemann 200-201. See also the discussion of citizenship in Ranciere, J. (2004) The politics of aesthetics (Rockhill, G.,Trans.). London and New York: Continuum.

${ }^{5}$ Mitchell, T.N. (1991). Cicero the Senior Statesman. New Haven: Yale University Press, 15 and 23-4.

${ }^{6}$ Aristotle, Politics, III: 4. (1932). Rackam, H. (Trans.). London: William Heinemann) 178-81.

${ }^{7}$ Lacey, W.K., (1978). Cicero and the end of the Roman republic. London: Hodder and Stoughton 93.

${ }^{8}$ Rawson, E. (1975). Cicero - A Portrait. London: Allen Lane, 247.

${ }^{9}$ Bolgar, V. (1959). The Concept of Public Welfare: An Historical Comparative Essay. 8 American Journal of Comparative Law 44, 53.

${ }^{10}$ See United States Tobacco Co v Minister for Consumer Affairs (1988) 20 FCR 520 at 527 (Davies, Wilcox and Gummow JJ), Onus v Alcoa of Australia (1981) 149 CLR 27 at 35 (Gibbs CJ).
} 
This is translated as ${ }^{11}$

We describe as a popular action one which looks to the public interest.

In essence, the actio conferred on citizens the right to enforce public duties even in the absence of an individual interest. The actio was not a single action, but rather comprised a class of actions available to address specific wrongs. ${ }^{12}$ These were listed at D 43.1.2.1 and included an action to enforce the performance of a public duty, as well as actions to remedy threatened harm to religious places, desecration of tombs or blockages of public highways.

The action to enforce a public duty was obviously the most important of these so far as Roman constitutional practice was concerned, as its broad terms enabled citizens to enforce rules of public law in a wide range of circumstances. One of these was of sufficient importance as to lead to the recognition of a specific action - the interdictum de homine libero exhibendo - which could be used to vindicate the public law duty not to detain people unlawfully or, to express it positively, the public law right to individual liberty, by enabling an applicant to seek an order compelling the defendant to produce the person wrongfully detained. Thus D. 43.1.2.1 states: ${ }^{13}$

The interdict requiring the production of a freeman in court is an example of one to compel the performance of an official duty.

The importance attached to the remedy, and to individual liberty, in the scheme of Roman public law is illustrated by two other statements in the Digest, D. 43.29.1.1

This interdict is provided for protecting freedom, so as to ensure that freemen are not retained by anybody.

and at D. 43.29.9 $9^{15}$

This interdict is available to all. For nobody is to be prohibited from favouring freedom.

As mentioned in Part 1, Tacitus wrote of the public good served by oratory, which could bring 'deliverance to persons in jeopardy' and 'strike fear and terror into the hearts of malignant foes.' This language of 'deliverance' lies at the heart of the matter considered in this article: Where society is detrimentally affected by a breach of the Constitution, or where powerless individuals could not protect their interests (even if they had standing), the actio popularis provided an avenue to vindicate wrongdoing.

\subsection{The Problem of Multiple Actions}

Roman law anticipated the inevitable problem that, in a system where standing to address public wrongs was so broad, there were multiple possible plaintiffs. To avoid multiple actions being brought over the same issue, the Digest stated that if more than one plaintiff with the same complaint presented themselves to the praetor, the praetor would give first preference to whichever plaintiff had a personal interest in the matter ${ }^{16}$ (in which case the actio popularis would arguably be redundant) or, if there was no such plaintiff, then to whichever plaintiff acting in the public interest was 'most suitable. ${ }^{17}$ Thereafter, a claim brought by any other plaintiff could be met with the defence of res judicata. ${ }^{18}$

\subsection{The Legacy of the Actio Popularis in Roman-Dutch Law}

The actio popularis became redundant after the Roman era. This is perhaps unsurprising, as its origins in a republican form of government meant there was little scope for its use in the monarchical states of post-Roman Europe. Nevertheless, its legacy was felt in modern legal systems.

An example of this is provided by South Africa, where the intderdictum de homine libero exhibendo which, as was indicated above, was an aspect of the actio popularis, survives under that country's Roman-Dutch common

\footnotetext{
11 Mommsen, T., Kreuger, P., Watson, A., Watson, A. (Trans. and Ed.). (1985). The Digest of Justinian. Philadelphia: University of Pennsylvania Press, 794.

12 Van der Vyver, J.T. (1978). 'Actiones populares and the problem of standing in Roman, Roman-Dutch, South African and American law' 3 Acta Juridica 191, 192.

13 Mommsen, above n 11, 568.

14 Ibid 616.

15 Ibid 617.

${ }^{16} \mathrm{D} 47.23 .3$.

$17 \mathrm{D}$ 47.23.2. Possibly the praetor would grant the action to whichever of the plaintiffs was the first to have lodged a claim.

18 D 47.23.3.
} 
law. The actio popularis was discussed at length in the case of Wood $v$ Ondangwa Tribal Authority, ${ }^{19}$ in which the appellants sought an interdict restraining the respondent from subjecting third parties to detention and assault The issue before the court was whether the appellants had standing to act on behalf of the third parties, who were unable to act because they were in detention.

In the course of his judgment, Rumpff $\mathrm{CJ}$ held ${ }^{20}$ that while the actio popularis in general had become redundant in Roman-Dutch law in the 16th century (and thus had not become part of South African law) the interdictum de homnine libero exhibendo should be treated as being sui generis and still available because it protected the fundamental interest of freedom of the person. ${ }^{21} \mathrm{He}$ further held that anyone who became aware of the fact that someone had been unlawfully deprived of liberty had standing to bring the interdict. Although Rumpff CJ said that, the applicant would be acting on behalf of the detained individual rather than on behalf of the public, it is nevertheless true that the interdictum shares with the actio popularis the enforcement of a duty against the public official - in this instance the duty not to detain a person unlawfully.

The idea of the public action was revived in South Africa's post-apartheid Constitution, as is discussed below.

\section{Modern Common and Statute Law Equivalents of the Actio Popularis}

In some jurisdictions, modern equivalents of the actio popularis have been created by the judiciary through their development of the common law, while in others such actions have been created by statute. ${ }^{22}$ Space prohibits discussion of all of them, but the following examples suffice to indicate how the need for a mechanism for the vindication of public rights has been recognised.

\subsection{The Brief Life of a Public Interest Action in English Common Law}

Although the actio popularis was never part of English common law, there was an interesting development which saw the short-lived recognition of a remedy very similar to it: In Gouriet v Union of Post Office Workers, ${ }^{23}$ the Court of Appeal held that if the Attorney-General declined to grant a relator action to a person wishing to sue in the public interest, the courts could grant that person a right to sue in their own name. ${ }^{24}$ The Court of Appeal decision was however soon overturned by the House of Lords in Gouriet v Union of Postal Workers, ${ }^{25}$ which restored the status quo ante - in other words, that once the Attorney-General had declined to grant his permission to launch a relator action, a person was without remedy.

\subsection{Standing Conferred through the Development of Common Law}

In other jurisdictions, courts have succeeded in developing the common law to the point where broad standing is conferred on public interest litigants. Examples of this are provided by Ireland, India, Tanzania and Canada:

In Ireland, the courts have widened standing so as to permit public interest litigants to bring constitutional cases. In Crotty v An Taoiseach, ${ }^{26}$ where the plaintiff alleged that the government was acting unconstitutionally in that it had not amended the Constitution before ratifying the Single European Act, Finlay CJ held that the plaintiff had standing on the ground that if the operation of a statute would affect every citizen, then every citizen had standing to challenge its constitutionality and did not need to demonstrate a special interest. ${ }^{27}$ Similarly, in S.P.U.C. $v$ Coogan ${ }^{28}$ Walsh $\mathrm{J}$ held that 'every member of the public has an interest in ensuring that the fundamental law of the State is not defeated'. In Iarnród Éireann $v$ Ireland, ${ }^{29}$ the court refined the rule established in Crotty v An Taioseach by differentiating between two types of constitutional challenge: those where it was improbable that a plaintiff with a special interest would emerge, in which case the courts would grant standing to any citizen; and those where a plaintiff with a special interest would probably emerge, in which

\footnotetext{
191975 (2) SA 295 (A). For a discussion of this case see Aronstam, P. (1976). Was the Interdict De Libero Homine Exhibendo Extended? 93 South African Law Journal 346, and Van der Vyver, above, n 12, 195-8.

${ }^{20}$ At 305[E]-306[F].

${ }^{21}$ At 308[B]-311[A].

22 See the discussion in Bonine, J. (1999). Standing to Sue: The First Step in Access to Justice. Retrieved from http://www2.law.mercer.edu/elaw/standingtalk.html\#fnB18

${ }^{23}$ [1977] 1 All ER 696.

${ }^{24}$ For a discussion of this case see Schoombee, J.T. (1978). Gouriet v Union of Post Office Workers: The short life of an English actio popularis. 11 Comparative and International Law Journal of South Africa 47.

${ }^{25}$ [1977] 3 All ER 70.

${ }^{26}$ [1987] 1 I.R. 713.

27 At 766.

${ }^{28}$ [1989] 1 IR 734.

${ }^{29}$ [1996] 3 IR 321.
} 
instances the courts would insist that a plaintiff be able to demonstrate such an interest before standing would be granted. The liberal rule of standing developed in Crotty $v$ An Taiseach was most recently applied in Digital Rights Ireland Ltd v Minister for Communication, Marine and Natural Resources, ${ }^{30}$ where McKechnie $\mathrm{J}$ held ${ }^{31}$

Ultimately, the Court has a duty to prevent the unconstitutional abuse of public power, be it through legislation or otherwise. Thus where it is clear that a particular public act could adversely affect the constitutional, European, or Convention rights of a Plaintiff, or indeed society as a whole, a more relaxed approach to standing may be called for in order for the Court to uphold that duty, and vindicate those rights.

In India, the rules of standing were relaxed following the decision of the Supreme Court in Maharaj Sing v State of Uttar Pradesh, ${ }^{32}$ in which the court held that it would not reject a claim brought in the interests of the community simply because the applicant lacked standing. Subsequently, in S. P. Gupta v Union of India (Judges' Transfer Case), ${ }^{33}$ the Supreme Court heard a case brought by legal practitioners who alleged that the transfer of judges from one court to another for political reasons was unconstitutional. ${ }^{34}$ None of the applicants had themselves suffered any damage as a result of this conduct but, in addressing the issue of standing, Bhagwati $\mathrm{J}$ held $^{35}$ that

If public duties are to be enforced and social collective "diffused" rights and interests are to be protected, we have to utilize the initiative and zeal of public-minded persons and organisations by allowing them to move the court and act for a general or group interest, even though they may not be directly injured in their rights.

For this reason he concluded ${ }^{36}$ that

..any citizen who is acting bona fide and who has sufficient interest has to be accorded standing.

This liberal approach to standing was followed in several subsequent cases, ${ }^{37}$ and the position, as stated by the Supreme Court in Fertilizer Corp. Kamgar v. Union of India ${ }^{38}$ is that

In simple terms, locus standi must be liberalised to meet the challenges of the times. Ubi just [sic] ibi remedium must be enlarged to embrace all interests of public minded citizens or organisations with serious concern for conservation of public resources and the direction and correction of public power so as to promote justice...

The common law has been similarly developed in Tanzania where, in Mtikila $v$ Attorney General, ${ }^{39}$ Lugakingira J held

In matters of public interest litigation this Court will not deny standing to a genuine and bona fide litigant even where he has no personal interest in the matter ... . [S]tanding will be granted on the basis of public interest litigation where the petition is bona fide and evidently for the public good and where the Court can provide an effective remedy.

and that

...if there should spring up a public-spirited individual and seek the Court's intervention against legislation or actions that pervert the Constitution, the Court, as guardian and trustee of the Constitution and what it stands for, is under an obligation to rise up to the occasion and grant him standing.

In Canada, in Canadian Council of Churches $v$ Canada (Minister of Employment and Immigration) ${ }^{40}$ the

${ }^{30}$ [2010] 3 IR 251.

31 At [49].

32 (1976) 1 SCR 1072.

33 AIR 1982 SC 149.

${ }^{34}$ For a discussion of this case see Cottrell, J. (1984). The Indian Judges Transfer Case. 33 International and Comparative Law Quarterly 1032. The Indian cases are also discussed in Reiser, R. (2013). Towards an actio popularis? Standing and traditional values: A comparative analysis. 2 Oxford University Undergraduate Law Journal 24, 31-2.

${ }^{35}$ Above n 33, 188.

${ }^{36}$ Ibid 192.

${ }^{37}$ Sunil Batra v. Delhi Admin. (1980) 2 SCR 557, Upendra Baxi v. State of Uttar Pradesh AIR 1987 SC 191 and Olga Tellis v. Bombay Mun. Corp. (1985) Supp (2) SCC 51.

38 (1981) 2 SCR 52.

${ }^{39}$ Unreported, High Court, Civ. Case 5 of 1993.

${ }^{40}$ [1992] 1 SCR 236. 
Supreme Court held that whether standing could be granted to a public interest litigant, depending on the seriousness of the issue, whether the plaintiff has a genuine interest in the issue (which does not require that the plaintiff be directly affected by the law being challenged) and whether there is no other reasonable way for the issue to be brought before the courts. In Canada (Attorney General) v. Downtown Eastside Sex Workers United Against Violence Society, ${ }^{41}$ the court moderated the third criterion so as to mean that standing will be grant so long as, taking all practicalities into account, a public interest action is $a$ reasonable way of the matter being litigated, rather than the only way. This development was significant in the circumstances, in which the plaintiffs were acting in the interests of sex workers who were either unwilling to court the publicity associated with bringing a claim or who lacked the means to do so. In other words, although potential plaintiffs with a direct interest could be identified, that did not deprive the public interest plaintiff from being given standing.

\subsection{Standing Conferred by a Constitution or by Statute}

The process of democratisation after the fall of communism in Eastern Europe saw a number of countries ${ }^{42}$ enact constitutional or statutory provisions giving citizens the right to challenge non-compliance with the constitution in accordance with the idea that protection of the democratic order would be maximised if citizens had the capacity to take legal action to defend it. ${ }^{43}$ This trend was followed in a number of other European jurisdictions. ${ }^{44}$ In Croatia for example, Art 38(1) of the Constitutional Act on the Constitutional Court of the Republic of Croatia 2002 states that

Every individual or legal person has the right to propose the institution of proceedings to review the constitutionality of the law and the legality and constitutionality of other regulations.

Similar developments have occurred elsewhere in the world: In the United Kingdom, s 4(3) of Schedule 1 of the Scotland Act 1998 c.46 (UK) allows 'any person' to bring an action challenging the constitutional validity of legislation enacted by the Scottish Parliament, or action by the Scottish executive, on the ground that it does not fall within the devolved competence of the Scottish government. The provision has been used in a number of cases, most recently in Imperial Tobacco Ltd v Lord Advocate ${ }^{45}$ (which contains a useful listing of earlier cases) and Christian Institute v Lord Advocate. ${ }^{46}$

In Nepal, Article 133(1) of the Constitution of Nepal 2015 states, in relation to the jurisdiction of the Supreme Court, that

Any Nepali citizen may file a petition in the Supreme Court to have any law or any part thereof declared void on the ground of inconsistency with this Constitution because it imposes an unreasonable restriction on the enjoyment of the fundamental rights conferred by this Constitution or on any other ground, and extra-ordinary power shall rest with the Supreme Court to declare that law void either ab initio or from the date of its decision if it appears that the law in question is inconsistent with the Constitution.

Article 133(2) confers on the Supreme Court the 'extraordinary power to issue necessary and appropriate orders' in determining cases, including 'the settlement of any constitutional or legal question involved in any dispute of public interest or concern'.

The Constitutions of several African countries confer broad standing in Constitutional matters. ${ }^{47}$ In Uganda, for example, the Constitution not only allows public standing, but casts a duty on citizens to act in defence of the Constitution: Section 3(4) of the Constitution states

\footnotetext{
${ }^{41}$ [2012] 2 SCR 524.

${ }^{42}$ Sadurski, W. (2005) Rights Before Courts: A Study of Postcommunist Courts in Central and Eastern Europe. Dordrecht: Springer, 5-6.

${ }^{43}$ See the discussion in Popescu, R. (2014) The Forms of Direct Democracy and Their Role in Ensuring Good Governance. 5 Romanian Journal of Comparative Law 126, 162-4 who points to Estonia, Lithuania, Romania and Venezuela as jurisdictions in which an actio popularis is available.

${ }^{44}$ Kilinç, B. (2016) Individual Application in Turkish Constitutional Adjudication. Palermo: Key cites Lichtenstein, Malta, Croatia, Georgia and Macedonia as jurisdictions which have created statutory actiones populares.

${ }^{45}$ [2012] UKSC 61.

46 [2016] UKSC 51.

${ }^{47}$ For a detailed discussion of the position in Uganda and Kenya see Polavarapu, A. (2016). Expanding Standing to Develop Democracy: Third-Party Public Interest Standing as a Tool for Developing Democracies. 41 Yale Journal of International Law, 106-52. As well as the provisions in Uganda, Kenya and South Africa discussed in this article, see also s 2(1) of the Constitution of the Republic of Ghana 1992, which entitles 'any person' to seek a declaration that an enactment or conduct is in breach of the Constitution as well as s 5(1) of the Constitution of the Republic of Gambia 1997, which is cast in similar terms to s 2(1) of the Ghanaian Constitution
} 
All citizens of Uganda shall have the right and duty at all times-

(a) to defend this Constitution, and in particular, to resist any person or group of persons seeking to overthrow the established constitutional order; and

(b) to do all in their power to restore this Constitution after it has been suspended, 136 overthrown, abrogated or amended contrary to its provisions.

The ability of citizens to take legal action to ensure compliance with the Constitution is given effect by s 50(1) states

Any person who claims that a fundamental or other right or freedom guaranteed under this Constitution has been infringed or threatened, is entitled to apply to a competent court for redress which may include compensation.

Similarly, s 137(3) states that

A person who alleges that-

(a) an Act of Parliament or any other law or anything in or done under the authority of any law; or

(b) any act or omission by any person or authority, is inconsistent with or in contravention of a provision of this Constitution,

may petition the constitutional court for a declaration to that effect, and for redress where appropriate.

In Kenya, s 22 of the Constitution of Kenya 2010 states as follows:

(1) Every person has the right to institute court proceedings claiming that a right or fundamental freedom in the Bill of Rights has been denied, violated or infringed, or is threatened.

(2) In addition to a person acting in their own interest, court proceedings under clause (1) may be instituted by...

(c) a person acting in the public interest ..

Perhaps the most comprehensive provision on standing is that contained in s 38 of the Constitution of the Republic of South Africa Act, ${ }^{48}$ which states as follows:

38. Anyone listed in this section has the right to approach a competent court, alleging that a right in the Bill of Rights has been infringed or threatened, and the court may grant appropriate relief, including a declaration of rights. The persons who may approach a court are-

(a) anyone acting in their own interest;

(b) anyone acting on behalf of another person who cannot act in their own name;

(c) anyone acting as a member of, or in the interest of, a group or class of persons;

(d) anyone acting in the public interest; and

(e) an association acting in the interest of its members.

Section 38(d) is obviously the most important of these provisions for the purposes of this article.

Although s 38 applies specifically to remedying infringements of the Bill of Rights contained in Chapter 2 of the Constitution, the Constitutional Court in Ferreira $v$ Levin $^{49}$ held that a broad approach to standing should be taken in relation to the enforcement of all parts of the Constitution - not only the Bill of Rights.

In applying s 38, the courts have been alive to the philosophy of social transformation underlying the Constitution: In Permanent Secretary, Department of Welfare, Eastern Cape v Ngxuza, ${ }^{50}$ Cameron J noted that the broad standing conferred by s 38 was designed to remedy the fact access to justice was beyond the financial reach of many people in South Africa, and that their rights could often be vindicated only by others acting on their behalf. ${ }^{51}$ In addressing the 'floodgates' argument, Cameron J held Even more blunt in its rejection of the floodgates argument was the court in Wildlife Society of Southern Africa and Others v Minister of Environmental Affairs and Tourism of the Republic of South Africa and Others, ${ }^{52}$ which held that it was sometimes 'necessary

\footnotetext{
48 No. 108 of 1996.

491996 (1) BCLR 1 (CC) per Chaskalson P at 99.

${ }^{50} 2001$ (4) SA 1184 (SCA) at 1194 B-C.

${ }^{51}$ See also Kruger v President of the RSA 2009 (1) SA 417 (CC) per Skweyiya J at 428 C-D.

521996 (3) SA 1095 (TkS).
} 
to open the floodgates in order to irrigate the arid ground below them. ${ }^{53}$

Thus in Lawyers for Human Rights and Another v Minister of Home Affairs and Another, ${ }^{54}$ the Constitutional Court held that the applicant had standing to sue in the public interest to challenge provisions of the Immigration $A c t^{55}$ on the ground that, because it permitted detention of unlawful migrants for longer than 48 hours, it was inconsistent with freedom of the person protected by s 12 of the Constitution and the s 35 right not to be detained for longer than 48 hours without being brought before a court. In finding that the applicants had standing, Yacoob J held that whilst it was not ordinarily in the public interest for proceedings to be brought in the abstract, there would be instances where it would be in the public interest even if there was no actual dispute. ${ }^{56}$

Of particular importance was the way in which 38(d) was used by litigants in two highly politically-charged cases: In Freedom Under Law v Acting Chairperson: Judicial Service Commission, ${ }^{57}$ in which the court held that the applicant organisation had standing to seek review the respondent's dismissal of a complaint made by members of the judiciary against a judge who they alleged had attempted improperly to influence members of the Constitutional Court. Streicher JA held that Freedom Under Law had a right, acting in the public interest, to ensure that the independence of the judiciary was upheld ${ }^{58}$ and indeed that ${ }^{59}$

...every South African citizen has an interest to be served by judges who are fit for judicial office, and by courts which are independent and impartial.

In similar vein, in Democratic Alliance v The Acting National Director of Public Prosecutions, ${ }^{60}$ Navsa JA held that a political party had standing both in its own interests and in the public interest to ensure that the rule of law was upheld. ${ }^{61}$ On this basis the court held that the appellant could initiate litigation seeking judicial review of the respondent's decision to discontinue a prosecution of President Jacob Zuma for corruption. The importance of these cases lies in the fact that under the South African Constitution, citizens are viewed as legitimate intervenors in public affairs through their enforcement of constitutional obligations against the branches of government, even in the absence of a personal interest being at stake, ${ }^{62}$ a philosophy that is radically different from that which has thus far prevailed in the common-law world in general and in Australia in particular.

These examples come from a variety of jurisdictions with different legal systems, however the policy underlying them is the same - namely that because every person has an interest in ensuring that the organs of the state are complying with the constitution, and because the duty to comply is not owed to any specific individual but rather to the people as a whole, the right to have the Constitution adhered to should be able to be vindicated by anyone acting in the public interest.

\section{The Current Law on Standing in Australia}

\section{1 'Matters' under Chapter III of the Constitution}

The question of when, and by whom, a case can be brought before the federal courts is governed by sections 75 and 76 of the Commonwealth of Australia Constitution Act 1901 (UK). These sections confer jurisdiction on the High Court and the other federal courts established by Chapter III of the Constitution. Sections 75 and 76 state that jurisdiction is conferred on these courts in relation to 'matters'. In In re Judiciary and Navigation Acts (Advisory Opinions Case), ${ }^{63}$ the High Court interpreted the word 'matters' as meaning that the for a Chapter III court to have jurisdiction, there has to be

... some immediate right, duty or liability to be established by the Court...we can find nothing in

\footnotetext{
${ }^{53}$ At 1106 per Pickering J who, interestingly from an Australian perspective, was quoting extra-judicial comments by Kirby P (as he then was).

542004 (4) SA 125 (CC).

55 No. 13 of 2002.

${ }_{56}^{56} 2004$ (4) SA 125 (CC) at 136.

${ }^{57} 2001$ (3) SA 549 (SCA).

58 At 556 B-C.

59 At 557 D-F.

${ }^{60} 2012$ (3) SA 486 (SCA).

${ }^{61}$ At 504.

${ }^{62}$ For a discussion of the application of rules of standing following the enactment of South Africa's post-apartheid Constitution, see Swanepoel, C.F. (2014). The judicial application of the "interest" requirement for standing in constitutional cases : "A radical and deliberate departure from common law" 47(1) De Jure 63 and Swanepoel, C.F. (2016). The Public Interest Action in South Africa: The Transformative Injunction of the South African Constitution. 41(2) Journal for Juridical Science 29.

${ }^{63}$ (1921) 29 CLR 257.
} 
Chapter III of the Constitution to lend colour to the view that Parliament can confer power or jurisdiction upon the High Court to determine abstract questions of law without the right or duty of any body or person being involved.

Applying this test, the court held that held that a provision contained in the Judiciary Act 1903 (Cth) which purported to allow the Attorney-General to approach the court for a ruling on the constitutionality of a legislative provision was itself unconstitutional because there was no controversy between opposing litigants for the court to decide. The decision in the Advisory Opinions Case is based on sound principle: The function of the courts is to decide disputes, not to answer legal questions in the abstract. If people could approach the courts requesting an answer to hypothetical legal questions, the courts would become providers of legal advice rather than institutions deciding disputes and their case-loads would become unmanageable.

\subsection{Standing}

Apart from the need for a controversy, the jurisdiction of the courts will be engaged only if a case is brought by parties who have standing - in other words, who have an interest in the outcome. Thus a mere academic disagreement between the parties over a legal point is not sufficient to establish standing. In the words of the court in the Advisory Opinions Case, there must be a 'right or duty of [a] person or body involved'. This rule is not unique to constitutional litigation - it is a long-established principle of common law.

Who then has standing? In other words, what constitutes a sufficient interest in the outcome of a dispute to found standing? The basic common law rule expressed in Boyce v Paddington Borough Council, ${ }^{64}$ adopted in Australia in Anderson $v$ Commonwealth, ${ }^{65}$ is that for a person to have standing, they must be vindicating their own private right or, where public rights - for example, non-compliance with a public duty - are in issue, a person must be able to demonstrate that his or her interests are particularly affected above and beyond those of the general public. If they are unable to do this, then it is up to the Attorney-General to bring an action on behalf of the public, using the standing which the Attorney-General has under the common law to pursue matters in the public interest - as held in Attorney - General (NSW) v Brewery Employees Union of NSW. ${ }^{66}$

If the Attorney-General declines to bring an action in the public interest, than a private person may request the permission of the Attorney-General to initiate relator proceedings. A relator proceeding is one in which the Attorney-General is the formal plaintiff while the person claiming to be aggrieved is the plaintiff in fact, who conducts and pays for the litigation. If the Attorney-General refuses to authorise relator proceedings, no action can be brought. A flaw in the relator process is that, whatever conventions might say about the independence of the Attorney-General, he or she is a member of cabinet, and so usually cannot be expected always to be willing to authorise proceedings against the government itself. ${ }^{67}$

Leaving aside the specific exception provided by the relator action, the rule applied by the High Court in Australian Conservation Foundation v Commonwealth ${ }^{68}$ is that in order to vindicate a public right or enforce a public duty, a plaintiff must be able to demonstrate a special interest in the matter - in other words, must stand gain some advantage or avoid some disadvantage in bringing the action. Importantly, the court held that a mere emotional or intellectual concern did not amount to a sufficient interest. For this reason the court denied standing to an environmental group seeking to challenge the government's decision to approve a resort on the grounds that the government had failed adequately to consider an environmental impact report, holding that, apart from sharing an interest in the environment, the members of the group had failed to show how they personally would be affected by the approval of the resort.

A more liberal approach to determining what constitutes a special interest was evident in Onus $v$ ALCOA, ${ }^{69}$ in which the court held that members of an Aboriginal group had standing to challenge the construction of a smelter at a sacred site because they were the traditional custodians of the site, there was a special cultural and spiritual significance to the site and the group visited the site regularly (Gibbs CJ). Although this approach was more generous than that in Australian Conservation Foundation, the court still retained the special interest test applied

\footnotetext{
${ }^{64}$ [1903] 1 Ch 109.

65 (1932) 47 CLR 50.

${ }^{66}$ (1908) 6 CLR 469

${ }^{67}$ See Mason, A. (2010) 'Access to Constitutional Justice: Opening Address' 23 Bond Law Review 1, 2 There is however at least one occasion on which the Attorney-General authorised relator proceedings against the government, in the case of Attorney - General (Cth); ex rel McKinley v Commonwealth (1975) 135 CLR 1.

${ }^{68}$ (1980) 146 CLR 493.

${ }^{69}$ (1989) 149 CLR 27.
} 
in that case. Thus Gibbs CJ held that a mere intellectual or emotional concern was insufficient to found standing, ${ }^{70}$ while Brennan J held ${ }^{71}$ that for standing to exist, a plaintiff must show that

...he has been specially affected, that is, in comparison with the public at large he has been affected to a substantially greater degree or in a significantly different manner.

This test for what constitutes a special interest was applied in subsequent cases: In Croome $v$ Tasmania ${ }^{72}$ the Court held that the applicant, who was gay, had sufficient standing to challenge the constitutionality of a Tasmanian statute that criminalised homosexual intercourse even though he himself had not been prosecuted under it. The fact that the threat of prosecution hung over him was, the High Court held, sufficient to give him an interest, and thus standing. In Pape v Commissioner of Taxation ${ }^{73}$ the High Court held that a taxpayer who was entitled to receive a $\$ 250$ bonus as part of an economic stimulus package had standing to contest the validity of the legislation authorising the payment of the bonus.

In Truth About Motorways Pty Ltd v Macquarie Infrastructure Investment Management Ltd, ${ }^{74}$ the court held that $\mathrm{s}$ 80 of the then Trade Practices Act 1974 (Cth) was constitutionally valid, even though it conferred very broad standing on 'any person' to seek an injunction to enforce the Act. The court held that the applicant company, formed by a group of activists to oppose the construction of a freeway by the respondents, had sufficient standing to bring a case alleging infringement of the Act because the members of the applicant company lived in areas where the motorway would be built. This case is of particular importance because it demonstrates that whereas, as was held in the Advisory Opinions Case, Parliament cannot confer jurisdiction in the absence of a controversy, it can determine who may be deemed to have standing once a controversy is found to exist.

\subsection{Matter and Standing - Two Requirements or One?}

In cases that have come before the courts in recent years, some of the Justices have treated the requirements of matter and standing as one. ${ }^{75}$ In Croome v Tasmania, ${ }^{76}$ Gaudron, McHugh and Gummow JJ held ${ }^{77}$ that

Where the issue is whether federal jurisdiction has been invoked with respect to a 'matter', questions of 'standing' are subsumed within that issue.

Similarly, in Abebe v Commonwealth ${ }^{78}$ Gleeson CJ and McHugh $\mathrm{J}$ held ${ }^{79}$ that the existence of a 'matter' means that a plaintiff

..must have sufficient interest in enforcing the right, duty or liability to make the controversy justiciable.

In Truth About Motorways Pty Ltd v Macquarie Infrastructure Investment Management Ltd, ${ }^{80}$ Gaudron J held ${ }^{81}$ that where the Attorney-General authorises relator proceedings, there is a matter (because the person on whose behalf the action is brought is seeking to establish a right, duty or liability) but the case is formally brought by the Attorney-General who does not have an interest in it and thus lacks standing. For this reason, she said, the issue of standing is 'subsumed' into that of matter. So long as there was a remedy which could be used to vindicate a right, duty or liability, there would be a 'matter'. She also held that there was nothing to prevent the legislature from vesting persons other than the Attorney-General with standing to bring actions in the public interest, as it indeed had done in s 80 of the then Trade Practices Act 1974 (Cth), which gave 'any person' the right to bring an action to enforce the Act.

In Pape v Commissioner of Taxation, ${ }^{82}$ Gummow, Crennan and Bell $\mathrm{JJ}$ held ${ }^{83}$ that

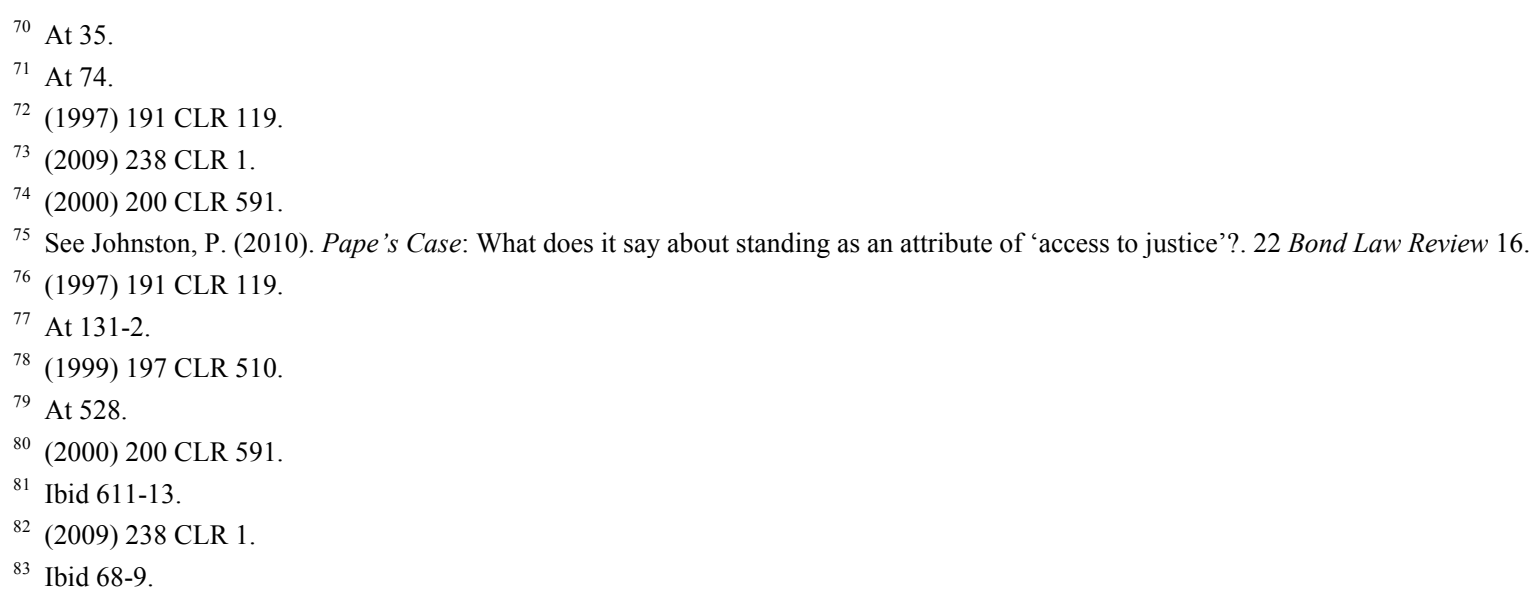


..questions of 'standing' to seek equitable remedies such as those of declaration and injunction are subsumed within the constitutional requirement of a 'matter'....

Despite this trend towards the conflation of matter and standing, conceptually they are separate and distinct: A matter requires that there be a dispute - that is, a question between parties which is not merely hypothetical, the determination of which will have an effect on rights and duties - while standing determines which specific parties have a sufficient interest in that dispute to enable them to approach the courts.

Can there be a matter without standing or vice versa? One could imagine that A and B have a dispute over some point of constitutional law, the determination of which would effect on the rights or duties of people, and for that reason there would be a matter. But if A and B themselves were not members of the set of people whose rights and duties would, be affected, they would not have standing. Thus, there can be a matter without anyone having standing to litigate it. On the other hand, if the rights of $\mathrm{C}$ and $\mathrm{D}$ would be affected by the outcome of a dispute, they would have standing, and the existence of a dispute affecting rights and duties presupposes matter. So there cannot be standing without a matter.

In practical terms, however, these arguments are otiose - practically speaking, in almost all cases matter and standing will coincide.

\section{A Critique of the Australian Law}

The approach to standing in Australia can be criticised on two grounds: First, the insistence that a litigant be able to demonstrate a personal interest in a matter order to have standing - and the corresponding denial of standing to a litigant who has 'only' a general interest in the maintenance of the constitutional order - weakens the defence of constitutionalism. Second, in practice, the requirement of a personal interest is unevenly applied, in that in several instances, political actors have been assumed to have standing without a personal interest having to be demonstrated.

\subsection{Insufficient Protection for Constitutionalism}

As indicated in Part 4.2 above, the leading case on standing in Australia is Onus v ALCOA. ${ }^{84}$ Although that case was welcome in so far as it marked a more generous approach to standing than had been adopted in Australian Conservation Foundation v Commonwealth ${ }^{85}$ by finding that the spiritual concerns of the Indigenous applicants amounted to a sufficient interest to found standing, the approach adopted in it can nevertheless be criticised on two grounds:

The first relates to the fact that it worked no fundamental change to the rules on standing, which still require proof of differential operation in relation to a specific plaintiff as distinct from an effect on the broader public. Yet, in many instances, differential effect on the individual may be slight and the interest or concern of the public as a whole may be of far greater importance - particularly in cases involving compliance with the Constitution.

The second criticism is that while the court in Onus v Alcoa took spiritual matters into consideration in assessing the interests of the applicants, it seems anomalous that the courts should not similarly consider philosophical concerns as being sufficient to found standing. Thus although the decision was undoubtedly liberal so far as Indigenous rights and spirituality were concerned, it was still conservative in its requirement that there be 'something more' than emotional or intellectual concern to establish standing. Why should an intellectual interest in a matter, or a secular concern for compliance with the Constitution, be any less entitled to be taken into consideration as a ground for standing than a spiritual one? Unfortunately, the courts have set their face against the conferral of standing on a plaintiff simply because he or she is a citizen with a general interest in the enforcement of the Constitution, as has been asserted in a number of cases. ${ }^{86}$ The only exception to this was the case of McDonald $v$ Cain, ${ }^{87}$ where a majority of the court ${ }^{88}$ held that voters had standing to seek a declaration that it would be unlawful to present a Bill changing electoral boundaries for assent where the Bill had allegedly not been passed in accordance with the Constitution.

\footnotetext{
${ }^{84}$ (1989) 149 CLR 27.

85 (1980) 146 CLR 493.

${ }^{86}$ See Victoria $v$ Commonwealth and Hayden (1975) 134 CLR 388 at 402 per Mason J, Attorney-General (Commonwealth), ex rel McKinlay v Commonwealth (1975) 135 CLR 1 at 26 per Barwick CJ, Ingram v Commonwealth and Peacock (1980) 54 ALJR 395 at 397 per Gibbs J, Attorney-General (Victoria); ex rel Black v Commonwealth (DOGS Case) (1981) 146 CLR 559 at 589 per Gibbs J and Eastgate v Rozzoli (1990) 20 NSWLR 188 at 200D - 201E per Kirby P.

${ }^{87}$ [1953] VR 411.

${ }^{88}$ Gavan Duffy J at 420 and Martin J at 427.
} 
The prevailing approach in Australia thus focuses on the impact of law on the individual, rather than the impact of law on society. Yet where the law in question is one relating to the Constitution, surely it should not be necessary to seek out a single, particular person who will be 'sufficiently' harmed or benefited by the law? The fixation on finding an individual with standing seems particularly inappropriate to field of constitutional law, as infringements of the Constitution necessarily affect all individuals within society, and ought therefore to be remediable on the suit of any member of society.

Under the current approach, breaches of the Constitution will be left unremedied in circumstances where no-one with a personal interest initiates legal action. In other words, whether an alleged breach of the constitution is able to challenged depends on whether an individual finds it to their own advantage to initiate a challenge rather than on the legal merits of the issue. This means that meritorious challenges may not be heard, and constitutional breaches thus allowed to stand, simply because no self-interested litigant comes forward. This is surely a paradox - the rules of standing are supposedly justified on the ground that they prevent litigation based on individual caprice, yet their effect is precisely the opposite: Only those legal questions in which some individual is found to have an interest will be litigated, while those that may be of great importance to the commonweal, but which do not serve an individual interest, will not be. The result of this is that the law effectively favours the selfish over the selfless.

\subsection{The Privileged Position Accorded to Political Actors as Litigants}

The second ground upon which the current law can be criticised is that, as the case law reveals, the personal interest requirement is applied unevenly: Standing is frequently accorded to political actors without any exploration of whether they have a personal interest, in contrast to the 'ordinary' litigant, who has to demonstrate that they are able to surmount the interest hurdle. In other words, the current law of is not only founded on a bad rule, that rule is unevenly applied.

This is evidenced by a number of significant constitutional cases in which the standing of plaintiffs was assumed apparently - as the issue was not argued - simply because of their political status. For example, in Cormack v Cope ${ }^{89}$ the High Court heard a challenge brought by two opposition senators alleging non-compliance with the process contained in s 57 of the Constitution for resolving disputes between the House of Representatives and the Senate. Similarly, in Victoria v Commonwealth (PMA Case) ${ }^{90}$ and Western Australia v Commonwealth (First Territorial Senators Case), ${ }^{91}$ the plaintiff States brought actions challenging compliance with s 57, along with the additional issue in the latter case of whether Parliament had the power to give representation to the Territories in the Senate. The territorial senators issue was again litigated at the instance of a State in Queensland $v$ Commonwealth (Second Territorial Senators Case). ${ }^{92}$ In Combet $v$ Commonwealth, ${ }^{93}$ two members of the court ${ }^{94}$ held that the shadow Attorney-General, in her capacity as an opposition Member of Parliament, had standing to challenge the validity of the expenditure of public money.

There have also been cases at State level in which political actors have been assumed to have standing. Thus in Trethowan $v$ Peden, ${ }^{95}$ standing was assumed when opposition MPs challenged the constitutionality of a Bill presented to the New South Wales Parliament. Similarly standing was assumed when opposition parliamentarians challenged the validity of a New South Wales Act in Clayton $v$ Heffron. ${ }^{96}$

In none of these cases, whether at Commonwealth or State level, did the courts address the issue of why politicians or States should have standing. Plainly one can understand why opposition senators would have a political interest in challenging the procedures whereby the government had passed legislation, and why, in a legislative chamber where representation is State-based, States would similarly have a political interest in not having their power diluted by conferring representation on Territories. But if members of legislative chambers and the entities to which seats are allocated in them are assumed to have standing to bring actions to ensure compliance with the Constitution, why should not individual citizens, who after all form the foundation of the state, not also have standing to do so?

\footnotetext{
89 (1974) 131 CLR 432.

${ }^{90}$ (1975) 134 CLR 81.

91 (1975) 134 CLR 201.

92 (1977) 1329 CLR 585.

93 (2005) 224 CLR 494.

${ }^{94}$ McHugh J at 556-7 and Kirby J at 620-1.

95 (1931) 31 SR (NSW) 183.

${ }^{96}$ (1960) 105 CLR 214.
} 
Furthermore, what if it was not in the political interests of actors such as senators and States to challenge a particular breach of the constitution? The result then would be that the Constitution would remain unenforced because its enforcement would be hostage to the interests of political actors. A counter-argument that might be raised is that in most, perhaps all, instances where a law has been invalidly enacted, there will eventually come a time when a plaintiff will be able to show that they have been personally affected through its operation, and that they will then have standing. That may be true in some instances but will not necessarily be true in all, and in any event misses the point that, as shown in the cases discussed above, political actors have not been required to wait until the law has operated on them - they have been deemed to have standing to initiate an immediate challenge. So the question remains as to why similar immediate standing should not be conferred on ordinary subjects of the law? In some cases their interest may be no less partisan than that of political actors. However in other cases, their interest may be altruistic rather than partisan, being motivated solely by a desire to uphold the doctrine of constitutionalism, particularly in circumstances where politicians have failed to take action to enforce the Constitution because it was not in their interests to do so.

\section{Arguments in Favour of Reform}

Although the rule that standing should be limited to litigants who have a real interest in cases has merit as a general principle, different considerations apply when it comes to constitutional law. This is because compliance with the Constitution is a legitimate concern of the public as a whole and also because it may not be possible for an individual to identify a specific personal interest which is at stake where the Constitution has been breached.

The rules as developed by the Australian courts make no allowance for these considerations. The High Court's insistence that sections 75 and 76 of the Constitution require that a party demonstrate sufficient personal interest to establish standing precludes plaintiffs from initiating action to enforce provisions of the Constitution in the absence of being able to demonstrate a direct impact on them.

\subsection{Recent Calls for Reform in Australia}

In light of this, Australian academics have called for reform to the rules on standing. In his critique of the current rules, Keyzer has started from the proposition that since the Constitution governs all, all should have the opportunity to ensure its compliance through the courts, and that therefore anyone who has a serious and arguable case relating to compliance with the Constitution should have a right to approach the courts for relief. ${ }^{97}$ He advances three arguments in support of this. ${ }^{98}$ The first is that litigation can provide a vehicle for freedom of political expression, as it is a method of arguing against the validity of government action. The second is that the rule of law confers a legitimate interest on everyone to know what the law - particularly the law of the Constitution - is, and to have available to them the remedy of declaration of invalidity where a law is unconstitutional. The third is that since sovereignty ultimately rests in the people, the people should have a right to approach the courts to ensure that the government is acting lawfully. Standing in constitutional matters therefore warrants special treatment.

In addressing the counter-argument that such a broad rule of standing might open the floodgates of litigation, Keyzer states ${ }^{99}$ that standing would still have to be demonstrated, but that

...the courts ought not exclude a person from access to constitutional justice on the basis of who they are. Instead, the courts can exclude people from access to constitutional justice on the basis of what they have argued.

In other words, under Keyzer's approach, the law would assume that all people have standing to ensure compliance with the Constitution and so whether the courts would intervene would depend only on whether a plaintiff could demonstrate that there is a justiciable question to be heard. Keyzer's argument is therefore not that no interest is requires, but rather that the law should recognise a different type of interest - in other words, his argument reconceptualizes what an interest entitled to its day in court is, and recognises that a litigant acting in the public interest is as much entitled to standing as one acting in their own personal interest.

Support for reform in Australia has also been voiced by Evans, who points out that the common law in Australia, as in many other jurisdictions, already recognises the rights of parties without a direct personal interest to bring habeas corpus applications. ${ }^{100}$ Such an application was brought in politically charged circumstances in the case

\footnotetext{
${ }^{97}$ Keyzer, P. (2010). Open Constitutional Courts. Leichhardt: Federation Press, 42.

${ }^{98}$ Ibid $123-4$

${ }^{99}$ Keyzer, P. (2010). Standing to Raise Constitutional Issues Reconsidered, Considered. 22 Bond Law Review 60,73.

${ }^{100}$ Evans, S. (2010). Standing to Raise Constitutional Issues Reconsidered. 22 Bond Law Review 38-59.
} 
of Ruddock $v$ Vadarlis, ${ }^{101}$ where the Federal Court recognised the standing of a lawyer to seek the writ on behalf of a group of refugees who had been rescued from the high seas by the captain of a merchant vessel, the M.V. Tampa, and who were subsequently detained by members of the Australian armed forces in order to prevent their landing in Australia. If broad standing can be granted to a person to vindicate the public rights of another and, conversely, to enforce a public duty not to infringe those rights, why should that principle not be broadened to allow any person standing to enforce other public duties? Of course, in the case of habeas corpus there is an identifiable person whose rights are being vindicated but, as Evans points out, ${ }^{102}$ it is precisely because in other cases where there is harm to the polity as a whole, rather than to any individual member of it, that the rules of standing need to be changed.

\subsection{A Rawlsian Argument for Reform}

Keyzer and Evans present convincing arguments to the effect that a broadening of the rules of standing would both strengthen constitutionalism and promote citizen engagement in public affairs. We would argue that reform of the rules of standing can also be justified on grounds of legal theory, specifically by John Rawls' theory of justice. ${ }^{103}$

Rawls' theory depends on imagining a game in which participants, situated in what is called the 'original position', ${ }^{104}$ are asked to devise fundamental values upon which a society's legal rules would be based. The catch is that the participants operate behind what Rawls called the 'veil of ignorance'105 - unaware what their identities would be in that society. Only once they had determined these fundamental values would they know what their gender, race, religion, sexual orientation and financial resources et cetera would be. Rawls concluded that in a situation where 'no one knows his place in society, his class position or social status; nor does he know his fortune in the distribution of natural assets and abilities, his intelligence and strength, and the like', ${ }^{106}$ rational participants would agree on what he called the 'liberty principle', namely that each person should have the fullest degree of liberty - that is, fundamental rights - as is consistent with everyone-else's equal liberty ${ }^{107}$ and that social and economic opportunities should be arranged so as to be of greatest benefit to the least advantaged and so that there is equality of opportunity (the 'equality principle'). ${ }^{108}$

In detailing what types of liberty rational participants would agree required protection, Rawls identified a number of liberties relating to processes, including the rule of law and the right to have compliance with rules of society adjudicated and enforced by independent courts. ${ }^{109}$ Although he did not specifically address the question of standing, we would argue that subjects in the original position would agree that open standing should be available, because open standing to enforce constitutional rules is required to give effect both to the liberty principle and the equality principle.

The liberty principle embraces open standing because subjects in the original position would want all citizens to have the ability to enforce constitutional rules in order to maximise the likelihood that liberty would be defended. They would also consider that open standing was supported by the equality principle because, even in a situation where formal equality before the law is protected, it does not necessarily follow that substantive equality is protected, and in many cases there will be educational, financial or other factors which prevented many people from bringing constitutional cases. ${ }^{110}$ For this reason, subjects in the original position would opt for open standing in order to increase the likelihood that were a constitutional matter to arise, someone with the wherewithal to bring it could do so, even if those more directly affected could not afford to do so.

The Rawlsian veil of ignorance speaks on a deep level to giving a voice to the voiceless. Although each subject behind the veil is an advocate for his own potential interests, the 'potential' nature of their ultimate

\footnotetext{
101 (2001) 110 FCR 452.

${ }^{102}$ Evans, above n 100, 47-8.

${ }^{103}$ Rawls, J, (1972). A Theory of Justice. Oxford: Clarendon Press.

104 Ibid 17-22.

105 Ibid 136-42.

${ }^{106}$ Ibid 137.

${ }^{107}$ Ibid, 60 .

108 Ibid, 60 and 303.

109 Ibid, 238-9.

${ }^{110}$ A 2012 survey conducted by the Law and Justice Foundation of New South Wales found that only 49-53\% of legal problems experienced by those surveyed resulted in the subjects seeking legal advice. See Coumarelos, C., Macourt, D., People, J., McDonald, H., Wei, Z., Iriana, R., Ramsey, S. (2012). Legal Australia-Wide Survey: Legal Need in Australia. Sydney: Law and Justice Foundation of New South Wales, xvi.
} 
characteristics means that they would equally act as an advocate for the worst off in society. This corresponds well with the duty of the engaged citizen as envisaged by Socrates, Cicero and Tacitus, who believed that the citizen owes a duty to question the law in the interests of society as a whole.

\section{Conclusion and the Way forward}

The key to understanding the actio popularis and its modern equivalents is not just that they confer standing on the citizen to obtain a remedy when the rules of the constitutional order are breached, but that they serve a higher value, which is that the citizen has a right to have constitutional law observed. In other words, the remedy is a necessary consequence of a more fundamental principle. In Australia, although most people would claim to support the doctrine of constitutionalism - in the abstract political sense - in that they would say that the citizen is entitled to have the Constitution complied with, that is very different from accepting - as a legal rule - the idea that every citizen has a right to approach the courts for a remedy when the Constitution is infringed. Yet, in accordance with the maxim ubi ius, ibi remedium, the commitment to constitutionalism is hollow unless a remedy exists to give effect to it. It is for this reason that the rules of standing need to be reformed. What needs to be done for this to be achieved?

As discussed in Part 4 of this article, rules on standing in Australia are founded on the interpretation given by the courts to the word 'matter' (which governs their jurisdiction under sections 75 and 76 of the Constitution) and their determination of what constitutes a sufficient interest to establish standing (which is governed by the common law). Although the common law rules relating to sufficient interest could be changed by ordinary legislation, this is not the case in relation to the meaning of the word 'matter' in sections 75 and 76, which could be changed only if the High Court could be persuade to overturn its long-standing decision in the Advisory Opinions Case $^{111}$ or if the Constitution was amended in accordance with the referendum procedure contained in $\mathrm{s} 128$. Each of these avenues presents difficulties: A change in the Court's interpretation of sections 75 and 76 could occur only if a suitable case came before the Court. Referenda to the Constitution rarely meet with success in Australia. ${ }^{12}$ We argue that such is the importance to the doctrine of constitutionalism of reform of the rules of standing, that the effort to achieve reform needs to be made, either by bringing a test case before the courts or by campaigning for a constitutional amendment. Irrespective of which avenue was used, we would suggest the following as a suitable text either of a new judicial interpretation of the Constitution or of a new section in the Constitution providing for open standing in constitutional matters:

A matter exists where a person acting in their own interest or in the public interest alleges that the Constitution has been infringed by act or by omission. Such a person may seek relief from a court exercising the judicial power of the Commonwealth and the court may make such orders it deems fit.

One would anticipate that the remedies most often sought by public-interest litigants would be declarations that legislation or government conduct was unlawful and / or mandatory or prohibitory injunctions. Damages would be available only where a person could demonstrate that they had suffered financial loss, although in that situation a litigant would have standing even under current rules. The fear that open standing would open a floodgate of litigation is unwarranted: In accordance with normal rules of procedure, applicants would have to overcome the hurdle of showing that they had a prima facie case. In circumstances where a large number of potential plaintiffs had standing, the floodgates issue could be managed by the courts in the same way as it is when members of a large class have standing in a civil action - that is, either by means of a representative action brought by one member of the group or by means of a class action. The courts would be able to exclude vexatious or frivolous litigants in accordance with usual rules of procedure.

The existence of a public interest action would be a spur to governmental compliance with the law, and would enhance the peoples' knowledge of, and commitment to, their Constitution. Open standing was recognised in ancient Rome as necessary for the protection of the constitutional order. Nowadays numerous jurisdictions provide for open standing in constitutional matters. There is no reason why Australia should not follow in their footsteps nor indeed hesitate in reaching back to an ancient principle in order to remedy a contemporary defect in our constitutional law. To adopt phraseology that echoes ancient Rome: Closed standing delenda est. ${ }^{113}$

\footnotetext{
111 (1921) 29 CLR 257.

112 Since 1901 there have been 44 referenda of which only eight have been successful.

${ }^{113}$ Whenever Cato the Elder participated in a senate debate on Rome's relations with Carthage, he would end his speech with the phrase 'Carthago delenda est' (Carthage must be destroyed'). See Plutarch Lives: Marcus Cato 27. (1914). Perrin, B. (Trans.). London: William Heinemann 382-3.
} 


\section{References}

Aristotle. (1932). Politics. Rackam, H. (Trans.). London: William Heinemann. https://doi.org/10.4159/DLCL.aristotle-politics. 1932

Aronstam, P. (1976). Was the Interdict De Libero Homine Exhibendo Extended? South African Law Journal,93, 346.

Bolgar, V. (1959). The Concept of Public Welfare: An Historical Comparative Essay. American Journal of Comparative Law, 8, 44. https://doi.org/10.2307/837164

Bonine, J. (1999). Standing to Sue: The First Step in Access to Justice. Retrieved from http://www2.law.mercer.edu/elaw/standingtalk.html\#fnB18

Cottrell, J. (1984). The Indian Judges Transfer Case. International and Comparative Law Quarterly, 33, 1032. https://doi.org/10.1093/iclqaj/33.4.1032

Coumarelos, C., Macourt, D., People, J., McDonald, H., Wei, Z., Iriana, R. \& Ramsey, S. (2012). Legal Australia-Wide Survey: Legal Need in Australia. Sydney: Law and Justice Foundation of New South Wales.

Evans, S. (2010). Standing to Raise Constitutional Issues Reconsidered. Bond Law Review, 22, 38.

Johnston, P. (2010). Pape's Case: What does it say about standing as an attribute of 'access to justice'? Bond Law Review, 22, 16.

Keyzer, P. (2010). Open Constitutional Courts. Leichhardt: Federation Press.

Keyzer, P. (2010). Standing to Raise Constitutional Issues Reconsidered, Considered. Bond Law Review, 22, 60.

Kilinç, B. (2016). Individual Application in Turkish Constitutional Adjudication. Palermo: Key.

Lacey, W. K. (1978). Cicero and the end of the Roman republic. London: Hodder and Stoughton.

Mason, A. (2010). Access to Constitutional Justice: Opening Address. Bond Law Review, 23, 1.

Mitchell, T. N. (1991). Cicero the Senior Statesman. New Haven: Yale University Press. https://doi.org/10.2307/j.ctt1xp3tcd

Mommsen, T., Kreuger, P., Watson, A., \& Watson, A. (Trans. and Ed.). (1985). The Digest of Justinian. Philadelphia: University of Pennsylvania Press.

Plato. (1914). Apology. Fowler, H.N. (Trans.). London: William Heinemann. https://doi.org/10.4159/DLCL.plato_philosopher-apology.1914

Plutarch. (1914). Lives: Marcus Cato. Perrin, B. (Trans.). London: William Heinemann.

Polavarapu, A. (2016). Expanding Standing to Develop Democracy: Third-Party Public Interest Standing as a Tool for Developing Democracies. Yale Journal of International Law, 41, 106.

Popescu, R. (2014). The Forms of Direct Democracy and Their Role in Ensuring Good Governance. Romanian Journal of Comparative Law, 5, 126.

Ranciere, J. (2004). The politics of aesthetics (G. Rockhill, Trans.). London and New York: Continuum.

Rawls, J. (1972). A Theory of Justice. Oxford: Clarendon Press.

Rawson, E. (1975). Cicero - A Portrait. London: Allen Lane.

Reiser, R. (2013). Towards an actio popularis? Standing and traditional values: A comparative analysis. Oxford University Undergraduate Law Journal, 2, 24.

Sadurski, W. (2005). Rights Before Courts: A Study of Postcommunist Courts in Central and Eastern Europe. Dordrecht: Springer.

Schoombee, J. T. (1978). Gouriet v Union of Post Office Workers: the short life of an English actio popularis. Comparative and International Law Journal of South Africa, 11, 47.

Swanepoel, C. F. (2014). The judicial application of the "interest" requirement for standing in constitutional cases: "A radical and deliberate departure from common law". De Jure, 47(1), 63.

Swanepoel, C. F. (2016). The Public Interest Action in South Africa: The Transformative Injunction of the South African Constitution. Journal for Juridical Science, 41(2), 29. https://doi.org/10.18820/24150517/JJS41.v2.3

Tacitus. (1914). Dialogue on Oratory. Peterson, W. (Trans.). London: William Heinemann.

Van der Vyver, J. T. (1978). Actiones populares and the problem of standing in Roman, Roman-Dutch, South 
African and American law. Acta Juridica, 3, 191.

\section{Copyrights}

Copyright for this article is retained by the author(s), with first publication rights granted to the journal.

This is an open-access article distributed under the terms and conditions of the Creative Commons Attribution license (http://creativecommons.org/licenses/by/4.0/). 